\title{
Comparing the Effects of Dexmedetomidine and Midazolam on Sedation in Children with Head Trauma to Perform CT in Emergency Department
}

\author{
Hojjat Derakhshanfar ${ }^{1}$, FarzadBozorgi ${ }^{2}$, Adel Hosseini ${ }^{1}$, Shamila Noori ${ }^{1}$, \\ Abolfazl Mostafavi ${ }^{1}$, Ali Sharami ${ }^{1}$, Seyyed Abbas Hashemi ${ }^{3}$ \\ ${ }^{1}$ Shahid Beheshti University of Medical Sciences, Tehran, Iran \\ ${ }^{2}$ Emergeny Medicine Department, Mazandaran University of Medical Sciences, Sari, Iran \\ ${ }^{3}$ Faculty of Medicine, Mazandaran University of Medical Sciences, Sari, Iran
}

\section{SUMMARY}

Many of the children referred to the emergency complain of head trauma. Children usually require sedition to reduce their failure and fear because of high activity and fear of performing computed tomography (CT). Dexmedetomidine and Midazolam belong to short-acting drugs for this purpose. This study aimed to compare the effect of the above mentioned drugs on sedition in children.

Children referred to the emergency department were randomly divided into two groups. Group A was sedated with $0.05 \mathrm{mg} / \mathrm{kg}$ IV Midazolam and group B with $2 \mu \mathrm{g} / \mathrm{kg}$ IV Dexmedetomidine over 10 minutes (loading dose), and then repeat boluses $2 \mu \mathrm{g} / \mathrm{kg}$ IV over 10 minutes. Measurements included induction time, recovery time, efficacy, side effects, complications, and failure with each drug and vital signs and RAMSY scale. SPSS V.20 was used for data analysis. $p<0.05$ was considered statistically significant.

Totally, 100 patients participated in the current study ( 44 girls and 56 boys). The mean and standard deviation of age was $5.3 \pm 2.5$ years. During the study, just 5 patients $(10 \%)$ from group A did not have appropriate sedition following the injection of first dose of Midazolam and received the second dose. However, in B group patients no such case was reported. No significant difference was observed among blood pressure, heart rate, respiration and RAMSY Scale among the groups.

No significant difference was seen between efficacy of Midazolam and Dexmedetomidine in pediatric sedation. More research should be done for generalization of our findings .

Key words: computed tomography, dexametazone, emergency medicine

Corresponding author:

FarzadBozorgi

e-mail: amamali110@gmail.com 


\section{INTRODUCTION}

Many of the children referred to the emergency complain of head trauma. In many cases, brain CT is needed to be performed as part of the diagnosis process. Performing CT usually fails in children because of high activity and fear of this process. Hence, in many diagnostic and therapeutic procedures such as computed tomography (CT) scan, sedition and immobilizing the children is considerable, because of increasing the rate of success in diagnosis $(1,2)$.

Sedition has to be provided in the shortest time with lowest complications in children, and the used drug has to provide appropriate level of consciousness and sedition and leave the lowest effect on vital and hemodynamic signs of the patient. Various drugs such as chlorohydrates and pentobarbital have been used to provide sedition in children. Currently, to provide sedition in emergency department patients, short-acting drugs are used to reduce complications and long recovery time of stay in the emergency (3-5). One of the discussed drugs is Dexmedetomidine. Dexmedetomidine agonist alpha 2 is an adenoreceptor used to provide sedition in adults hospitalized in ICU since 1999 after confirmation of FDA. This drug is fast-acting with the half-life of 3 to 5 hours which in addition to its sedative effect has analgesic effect as well (6). On the other hand, benzodiazepines have also been used to provide sedition in children, and Midazolam can be referred to as a fast-acting benzodiazepine with short half-life. The current study aimed to evaluate the effect of Dexmedetomidine and Midazolam on providing sedition in children who were referred to the emergency department with head trauma.

\section{PATIENTS AND METHODS}

This randomized double blind clinical trial was done in Emergency Department of Immam Hossein Hospital, during 2013. The referred children, between 2 to 12 years of age who complained of head trauma and needed to have brain CT performed were included into the study population. Patients who suffered from unstable vital signs, or trauma in the areas except head, fracture and/or uncontrollable bleeding, deep tissues injury such as tendon, main arteries, patients with respiratory infection, allergy to the drugs used in the current study, and patients who used pain killers were excluded from the study. Before participating in the study and providing sedition, patients ' parents completed the consent form and were aware of the plan. Hence, patients were randomly divided into two groups. In group $\mathrm{A}$, $0.05 \mathrm{mg} / \mathrm{kg}$ Midazolam was injected intravenously in a dose, and the dose was repeated if needed. In group B, Dexmedetomidine $2 \mu \mathrm{g} / \mathrm{kg}$ was injected intravenously during $10 \mathrm{~min}$ as the primary dose; then, the same quantity was repeated as a secondary dose. Injection was performed by the emergency medical resident who did not know the name of the medication and grouping. Age, gender, sedition drug, time to achieve sedition and consciousness were recorded in patient's information sheet, according to Ramsy scale. To measure the level of sedition and analgesia in patients, Ramsy scale was used. Vital signs such as blood pressure (BP), O2Sat, pulse rate $(P R)$, respiratory rate (RR) and Ramsy scale of patients were measured 5 and $10 \mathrm{~min}$ after injection, before and after performing CT. To analyze data, SPSS software was employed $(p<0.05)$.

\section{RESULTS}

Totally, 100 patients (44 girls and 56 boys) participated in the current study. The mean and standard deviation of age was $5.3 \pm 2.5$ years. Table 1 shows patients`demographic information. 
Table 1. Demographic characteristic of patients

\begin{tabular}{|c|c|c|c|}
\hline \multirow{2}{*}{ variable } & & \multicolumn{2}{|c|}{ Group } \\
\hline & & I & II \\
\hline \multirow{2}{*}{ Age } & Mean \pm SD & $5.7 \pm 2.5$ & $5 \pm 2.5$ \\
\hline & Median (range) & $5(2$ to 10$)$ & $4.3(2$ to 10$)$ \\
\hline \multirow{2}{*}{ Gender } & $\mathrm{F}$ & $20(40 \%)$ & $24(48.0 \%)$ \\
\hline & M & $30(60 \%)$ & $26(52.0 \%)$ \\
\hline \multirow{2}{*}{ Weight } & Mean \pm SD & $15.8 \pm 3.3$ & $15.4 \pm 3.7$ \\
\hline & Median (range) & 15 (10 to 23 ) & 15.5 (9 to 21 ) \\
\hline \multirow{2}{*}{ SBP.Presedation } & Mean \pm SD & $96 \pm 7$ & $97 \pm 5$ \\
\hline & Median (range) & 95 (90 to 110 ) & 100 (90 to 105$)$ \\
\hline \multirow{2}{*}{ DBP.Presedation } & Mean \pm SD & $65 \pm 5$ & $62 \pm 4$ \\
\hline & Median (range) & 60 (60 to 70$)$ & 60 (60 to 70$)$ \\
\hline \multirow{2}{*}{ PR.Presedation } & Mean \pm SD & $95 \pm 8$ & $94 \pm 9$ \\
\hline & Median (range) & 100 (75 to 106$)$ & 96 (82 to 120$)$ \\
\hline \multirow{2}{*}{ RR.Presedation } & Mean \pm SD & $18 \pm 3$ & $19 \pm 3$ \\
\hline & Median (range) & 18 (14 to 24$)$ & 20 (15 to 24$)$ \\
\hline \multirow{2}{*}{ O2.Presedation } & Mean \pm SD & $97 \pm 1$ & $97 \pm 1$ \\
\hline & Median (range) & 97 (94 to 98 ) & 96 (94 to 99) \\
\hline
\end{tabular}

During the study, only 5 patients $(10 \%)$ from group A did not have appropriate sedition following the injection of the first dose of Midazolam and received the second dose; however, in group B patients no such case was reported.

Average length of stay in the emergency department for group A was $44.1 \pm 6.3 \mathrm{~min}$ and for group $\mathrm{B}$ was $46.7 \pm 10.2 \mathrm{~min}$, and no significant difference was observed between the groups. Also, no significant difference among systolic and diastolic blood pressure, heart rate, respiratory rate, and
Ramsy scale in the groups was observed. During the study, just two cases of agitation were reported in patients of Midazolam group. No $\mathrm{O} 2$ sat and hypoxia were reported in the groups. Changes in systolic and diastolic blood pressure, heart rate, respiratory rate, $\mathrm{O} 2$ and Ramsy scale have been provided in figures 1 to 6. Mixed Model analysis showed that there was no statistical difference between two groups regarding the trend of systolic blood pressure (SBP), diastolic blood pressure (DBP), PR, RR and O2SAT over the study follow-ups. 
Original article

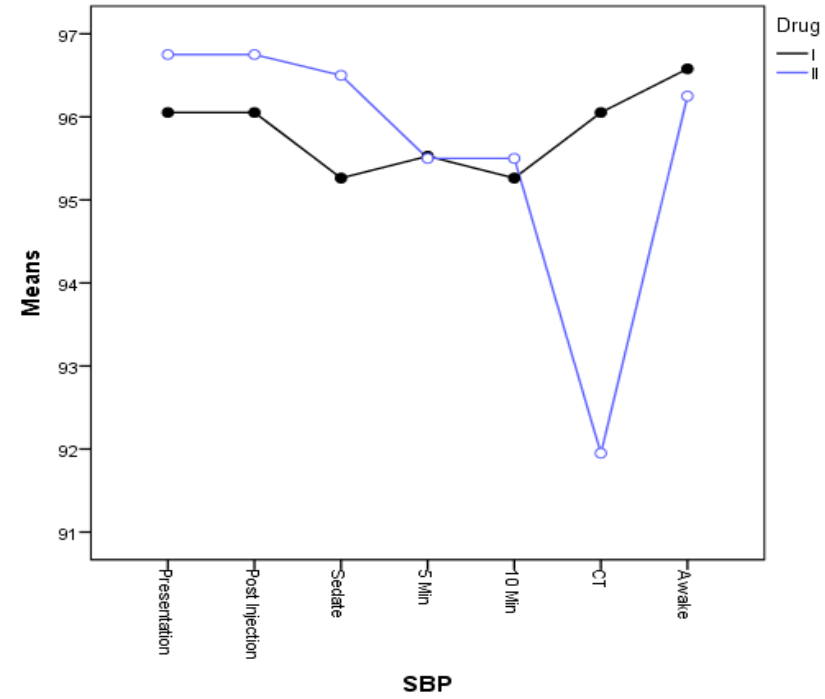

Figure 1: SBP changes among study groups

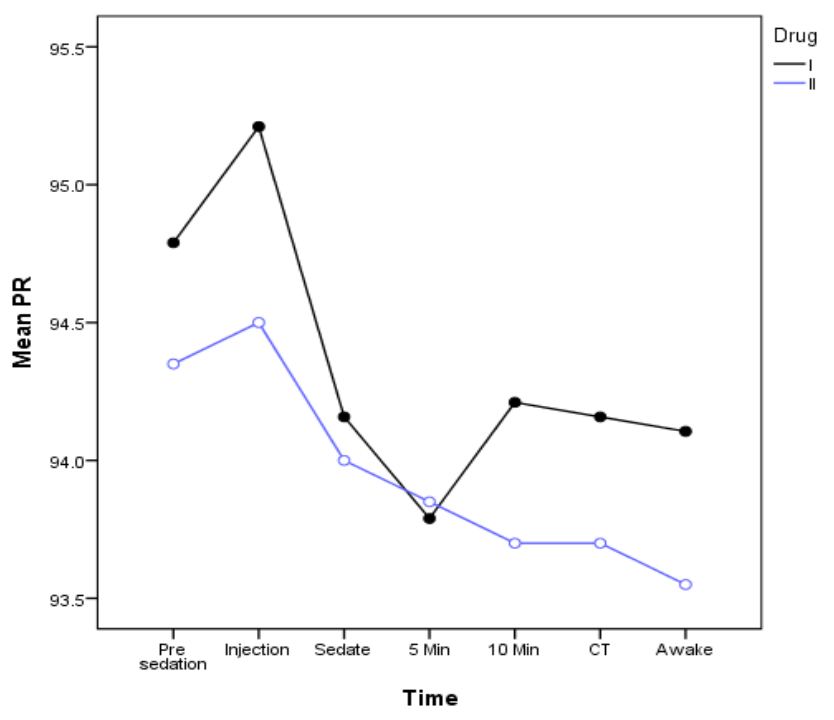

Figure 3: PR changes during the study among study groups

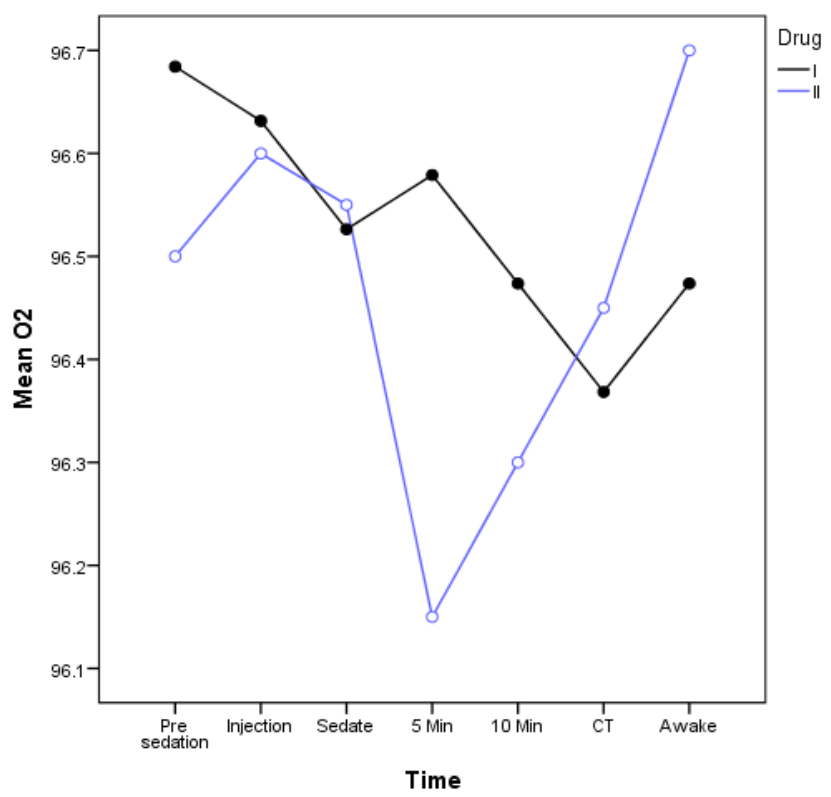

Figure 5: 02 changes during the study among 62 study groups

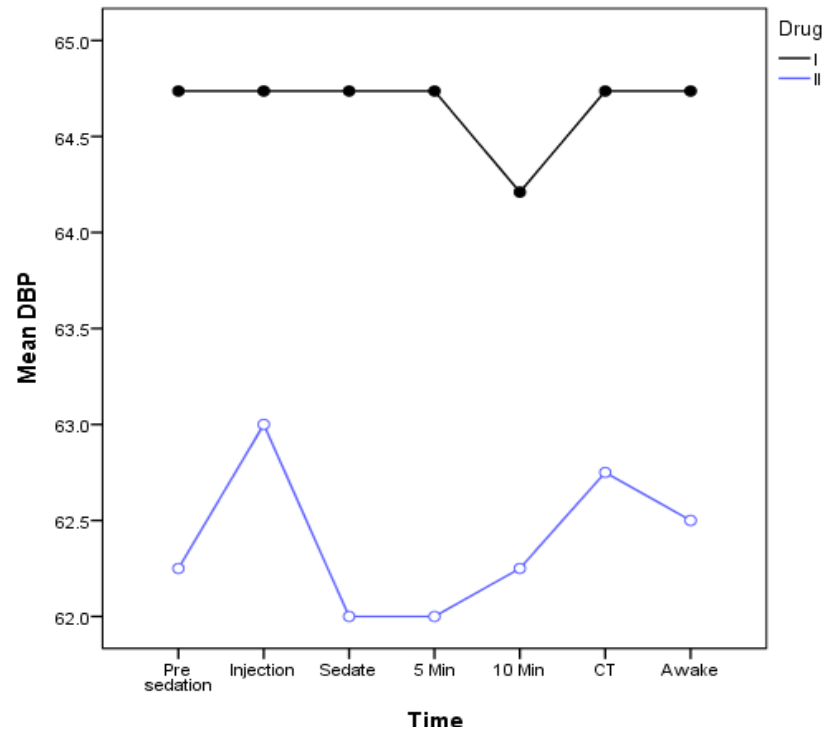

Figure 2: DBP changes among study groups

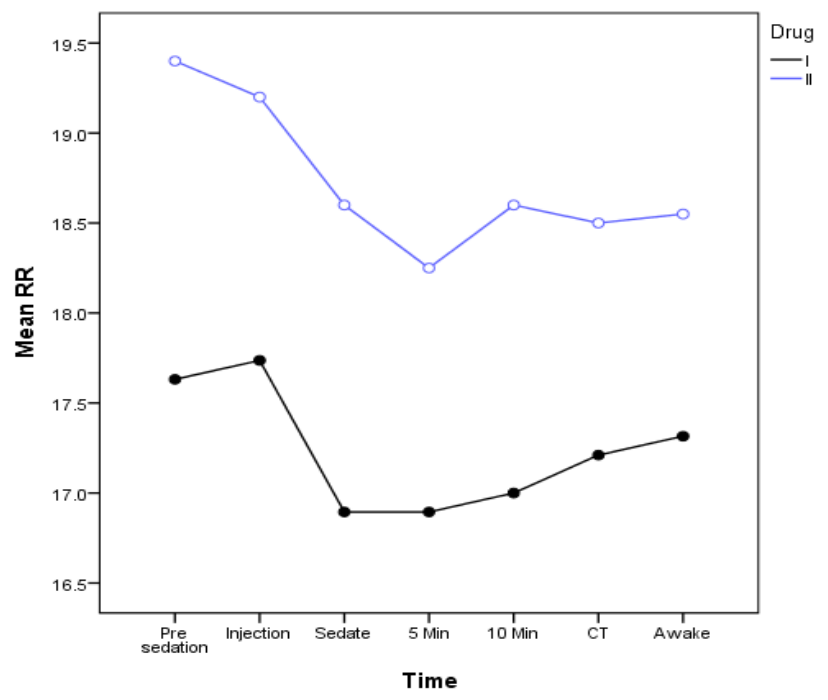

Figure 4: RR changes during the study among study groups

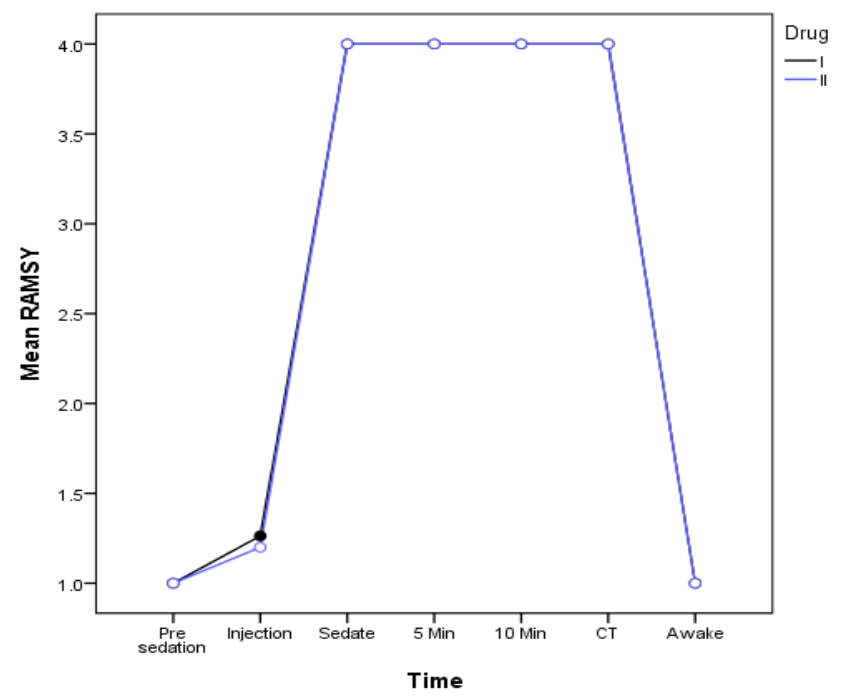

Figure 6: RAMSY changes during the study among study groups 


\section{DISCUSSION}

Results of the current study showed that there is no significant difference between applying Midazolam or Dexmedetomidine to provide sedition in children between 2 to 12 years of age. Since 1970 and following the use of CT as a diagnostic tool, the need to immobilize children during the performance of this process is considerable. Therefore, different drug protocols were hitherto applied to provide sedition in children to perform CT. In different studies, the rate of successful sedation in children has been reported as $87 \%$ to $98 \%$. The aim of sedation in children is to create the perfect immobility in the shortest possible time with the minimum time to sober up, because increasing the time of sedition leads to increase of drug side effects. Drugs used so far to provide sedation in children are Cholorohydrates and Pentobarbitals. These drugs have long-term effect which causes increase of the recovery time and level of side effects $(7,8)$.

In recent years, different studies have been conducted to evaluate short-term drugs. One of these drugs is Dexmedetomidine which temporarily causes hypotension and bradycardia, and the recovery does not need any special treatment $(9,10)$. In some studies, cardiovascular complications have been reported for Dexmedetomidine. Additionally, Dexmedetomidine may lead to hemodynamic instability during the recovery in some patients. In addition to FDA approval for sedition of adults in ICU, infusion and/or using it for children is still under consideration. Since 2005, Dexmedetomidine has been used as an alternative to pentobarbital in some medical centers. According to the performed studies, Dexmedetomidine as a sedative drug with short half-life is an appropriate alternative to pentobarbital (7).

Respiratory depression is the side effect of sedation in patients. The incidence of this complication has been reported as 5.5\% in different studies. Studies performed on Dexmedetomidine showed that in case of administration of this medicine rapidly, in less than 2 minutes, this side effect increases; otherwise, this side effect rarely occurs during the use of Dexmedetomidine. Results of a study which evaluated the incidence of respiratory symptoms among patients, after sedation with Propofol or Dexmedetomidine, showed that Exmedetomidine was an appropriate alternative to Propofol for patients at risk for respiratory depression $(5,6,9)$.

Midazolam is a short-term benzodiazepine, and in addition to its sedative affect it is hypnotic and anti-anxiety. In different studies, Midazolam dosage has been reported as $0.05-0.5 \mathrm{mg} / \mathrm{kg}$ over 2-3 minutes. In the performed studies, Midazolam has had side effects such as respiratory depression and cardiovascular dysfunction. Also, side effects such as vomiting, nausea, dysphoria have been reported. Researchers believe that using Midazolam antidote (flumazenil) at the time of its administration is necessary (3).

Conducted studies show that the level of sedition failure in children following the use of Dexmedetomidine and Midazolam are $2 \%$ and $7.75 \%$, respectively. However, these drugs have been reported successful in most of the patients. No study has compared Dexmedetomidine and Midazolam to provide sedition in children for performing CT. No significant difference was observed between the effects of these drugs in providing sedition for patients referring to the ICU which is compatible with the findings of the current study. In the study which has compared the effect of Dexmedetomidine and Midazolam on patients undergoing cataract surgery, Dexmedetomidine showed no preferences over Midazolam and has the same performance which is compatible with the results of the present study $(7,8,9)$.

There were some limitations in the current study, and the small population of patients in the study was the most important one. The lack of previous studies and protocols for patients who just suffered from isolated head trauma was another limitation of the current study.

The results of the current study showed that the use of Dexmedetomidine and Midazolam to provide sedition in children between 2 to 12 years old was successful and no significant difference was observed. In this regard, performing retrospective and prospective studies are recommended.

\section{Acknowledgments}

We gratefully acknowledge the contributions that were made by all of the participants during the workshop discussions. 


\section{References}

1. Schulte-Uentrop L, Goepfert MS. Anaesthesia or sedation for MRI in children.CurrOpinAnaesthesiol 2010;23(4):513-7. http://dx.doi.org/10.1097/ACO.0b013e32833bb52 4

2. Buck ML, Willson DF. Use of dexmedetomidine in the pediatric intensive care unit. Pharmacotherapy 2008;28(1):51-7. http://dx.doi.org/10.1592/phco.28.1.51

3. Lubisch N, Roskos R, Berkenbosch JW. Dexmedetomidine for procedural sedation in children with autism and other behavior disorders.PediatrNeurol 2009;41(2):88-94. http://dx.doi.org/10.1016/j.pediatrneurol.2009.02.006

4.Pant D, Sethi N, Sood J. Comparison of Sublingual Midazolam and Dexmedetomidine for Premedication in Children. Minerva Anestesiol 2013: 23. [Epub ahead of print]

5. Zhang X, Bai X, Zhang Q, Wang X, Lu L.The safety and efficacy of intranasal dexmedetomidine during electrochemotherapy for facial vascular malformation: a double-blind, randomized clinical trial. J Oral Maxillofac Surg 2013;71(11):1835-42. http://dx.doi.org/10.1016/j.joms.2013.06.202

6. Ihmsen $H$, Saari TI. Dexmedetomidine
Pharmacokinetics and pharmacodynamics].Anaesthesist 2012;61(12):1059-66.

http://dx.doi.org/10.1007/s00101-012-2114-1

7. Fagin A, Palmieri T, Greenhalgh D, Sen S.A comparisonof dexmedetomidine and midazolam for sedation in severe pediatric burn injury.J Burn Care Res. 2012 ;33(6):759-63. http://dx.doi.org/10.1097/BCR.0b013e318254d48e

8. Lam F, Ransom C, Gossett JM, Kelkhoff A, Seib PM, Schmitz ML, Bryant JC, Frazier EA, Gupta P.Safety and efficacy of dexmedetomidine in children with heart failure.Pediatr Cardiol 2013;34(4):835-41. http://dx.doi.org/10.1007/s00246-012-0546-7

9. Akin A, Bayram A, Esmaoglu A, Tosun Z, Aksu R, Altuntas R, Boyaci A. Dexmedetomidine vs midazolam for premedication of pediatric patients undergoing anesthesia.Paediatr Anaesth 2012 ;22(9):871-6. http://dx.doi.org/10.1111/j.1460-9592.2012.03802.x

10. Aksu R, Kumandas $S$, Akin $A$, Bicer $C$, Gümüş $H$, Güler G, Per H, Bayram A, Boyaci A. The comparison of the effects of dexmedetomidine and midazolam sedation on electroencephalography in pediatric patients with febrile convulsion.Paediatr Anaesth 2011;21(4):373-8 http://dx.doi.org/10.1111/j.1460-9592.2010.03516.x 


\title{
Upoređivanje efekata deksmedetomidina i midazolama na sedaciju dece sa povredom glave radi snimanja CT-om na Odeljenju urgentne medicine
}

\author{
Hojjat Derakhshanfar ${ }^{1}$, Farzad Bozorgi ${ }^{2}$, Adel Hosseini ${ }^{1}$, Shamila Noori ${ }^{1}$, Abolfazl Mostafavi ${ }^{1}$, Ali \\ Sharami ${ }^{1}$, Seyyed Abbas Hashemi ${ }^{3}$ \\ ${ }^{1}$ Univerzitet medicinskih nauka Shahid Beheshti, Teheran, Iran \\ ${ }^{2}$ Odeljenje urgentne medicine, Univerzitet medicinskih nauka Mazandaran, Sari, Iran \\ ${ }^{4}$ Medicinski fakultet, Univerzitet medicinskih nauka Mazandaran, Sari, Iran
}

\section{SAŽETAK}

Veliki broj dece koja se upućuju na Odeljenje urgentne medicine javlja se zbog povreda glave. Najčešće se deci daju sedativi kako bi se umirila i savladala strah zbog CT snimanja. Deksmedetomidin i Midazolam pripadaju grupi brzo-delujućih lekova koji se primenjuju u ove svrhe. Cilj ove studije bio je upoređivanje efekata pomenutih lekova na umirenje dece.

Deca koja su upućena na Odeljenje urgentne medicine nasumice su podeljena $u$ dve grupe. Deci iz grupe A je dat Midazolam IV u dozi od 0,05 mg/kg, a grupi B Deksmedetomidin u dozi od $2 \mu \mathrm{g} / \mathrm{kg}$ u trajanju od 10 minuta (početna doza), a potom i ponovljena doza od $2 \mu \mathrm{g} / \mathrm{kg}$ u trajanju od 10 minuta. Merenja su uključila vreme indukcije, vreme oporavka, efikasnost, propratne efekte, komplikacije, neefikasnost svakog leka pojedinačno, vitalne znake i Ramsy skalu. Za analizu podataka korišćena je SPSS verzija 20 . Kao statistički značajna vrednost uzeta je $\mathbf{p}<0,05$.

U studiji je učestvovalo ukupno 100 bolesnika (44 devojčice i 56 dečaka). Srednja i standardna devijacija godina starosti iznosila je $5,3 \pm 2,5$ godina. $U$ toku studije, samo $5(10 \%)$ bolesnika iz grupe A nije bilo dovoljno umireno nakon prve doze Midazolama, te im je data druga doza. Nije uočena statistički značajna razlika među grupama u vrednostima krvnog pritiska, srčanog rada, respiracije i RAMSY skale.

Nije pronađena statistički značajna razlika u efikasnosti Midazolama i Deksmedetomidina za umirenje pedijatrijske populacije. Neophodno je sprovesti nova istraživanja za izvođenje opštih zaključaka o dobijenim rezultatima.

Ključne reči: kompjuterizovana tomografija, deksametazon, urgentna medicina 